\title{
FIQH PRIORITAS SEBAGAI INSTRUMEN IJTIHÂD MAQÂSTIDÎ PERSPEKTIF YÛSUF AL- QARÂDAWÎ DAN URGENSINYA DI ERA KONTEMPORER
}

\author{
Nashrun Jauhari \\ Institut Agama Islam Abdul Halim Pacet Mojokerto, Indonesia \\ E-mail: ratnasuraiya@ymail.com
}

\begin{abstract}
The article attempts to analyze Fiqh of Priority as an instrument of ijtihâd maqâsidî from Yûsuf al-Qarâdawî̀s perspective and its significance within the contemporary era. The position of the Fiqh of Priority within the study of Islamic law is a part of the conceptual developments of ijtihâd which is based on maqâsid alshari'ah and has been oriented into Fiqh of $\mathrm{Da}$ 'wah. The Fiqh of Priority along with its principles can be functioned as a reference in stipulation of the Islamic law (ijtihâd al-ablâm). This is because the Fiqh of Priority is built on the priority values revealed in al-Qur'ân and mentioned in Hadith as well as based on the concept of tadarruj al-abkam (gradation of stipulation of the Islamic law) during the Prophet Muhammad's lifetime. Epistemo-logical framework of the Fiqh of Priority consists of three main principles, i.e. the principles of gradation in the Islamic law (al-fiqh bi marâtib al-a'mâl), the principles of attitude towards the reality of law (fiqh al-wâqi' li alabkâm), and the principles of dealing with contradiction between arguments or reasoning between the stipulation of law and social reality.
\end{abstract}

Keywords: Islamic law; Fiqh of Priority; ijtihâd maqâsidî̀.

\section{Pendahuluan}

Sebagaimana layaknya sebuah produk pemikiran, nilai-nilai dan prinsip-prinsip universal Islam yang sudah diteorikan oleh para ulama ke dalam terma maqâsid sharî́ah terus mengalami perkembangan. Konsep ijtihâd maqậsidî awalnya merupakan sebuah konsep nilai yang diangkat sebagai acuan ijtihad abad 19 oleh Ibn 'Âshûr untuk mengimplementa - 
sikan nilai-nilai maqâsid sharîah pada tataran praktis hukum secara optimal. Untuk tahap berikutnya, konsep ijtihâd maqâșidî juga mengalami perkembangan yang cukup signifikan, khususnya saat dieksplorasi beberapa pakar maqâsid abad 20 seperti Ṭ̂hha Jâbir al-'Alwânî, Aḥmad alRaysûnî, dan Yûsuf al-Qaraḍ̂âi.

Tantangan dunia kontemporer telah menambah tumpukan persoalan hukum yang belum bisa diselesaikan walaupun dengan menggunakan pendekatan ijtihâd maqâsịî̀ dalam bentuk konsepnya yang umum. Problematika hukum tersebut membutuhkan perhatian khusus, sehingga solusi hukum yang dihasilkan benar-benar tepat mengenai sasaran dan tujuannya. Untuk itu, beberapa pakar maqâsid kontemporer merumuskan sejumlah instrumen ijtihâd maqậsidî menurut ruang lingkup persoalan yang dihadapi.

Kertas kerja ini akan mengamati sejauh mana urgensi penerapan ijtihâd maqâsidî di era kontemporer seperti sekarang ini dan perkembangan konsepnya. Pun akan dianalisa tentang konsep Fiqh Prioritas Yûsuf al-Qarâtâwî dan pada sisi manakah Fiqh Prioritas diturunkan dari konsep besar ijtihad yang berbasis maqâsid sharî $a h$ ini.

\section{Sketsa Biografis Yusuf al-Qaradâwî}

Nama lengkapnya adalah Yûsuf b. 'Abd Allah b. 'Alî b. Yûsuf alQaraḍ̂âî. Ia dilahirkan di sebuah desa bernama Șafị Turâb propinsi Gharbîyah (Mesir) pada tanggal 9 September 1926. Semenjak usia 10 tahun ia sudah hafal al-Qur'ân. Semua jenjang pendidikannya ditempuh di lembaga pendidikan al-Azhar bahkan hingga ke tingkat perguruan tinggi. Untuk strata satu al-Qaraḍâwî belajar di fakultas Uṣûl al-Dîn yang lulus tahun 1952. Tapi gelar doktornya baru diperoleh pada tahun 1973 pada universitas yang sama dengan disertasi berjudul "al-Zakâh wa Atharuhâ fî Hịll al-Mashâkil al-Ijtimâ‘îyah” (Zakat dan Pengaruhnya dalam Menanggulangi Problematika Sosial). Disertasi ini kemudian menjadi sebuah kitab populer yang membahas masalah zakat di era modern secara lengkap. ${ }^{1}$

Al-Qaraḍ̂âî dikenal sebagai alim yang prolifik dan aktif memberikan kontribusi fatwa di berbagai media massa. Karya-karya tulis al-Qaraḍ̂â̂

1 'Abd al-'Ażìm al-Dayb, "Kata Pengantar: "Tarjamah Mûjizah 'an al-Shaykh Yûsuf alQaraḍ̂âî, dalam 'Abd al-Qâdir Mạ̣mûd al-Bakâr (ed.), Yûsuf al-Qaradânî: Kalimât fî̀ Takrîmih wa Buḥ̂th fî Fikerih wa Fiqhih, Vol. 1 dan 2 (Kairo: Dâr al-Salâm, 2004), 19. 
hingga saat ini mencapai jumlah ratusan buku. Melalui karya-karya tersebut dan dari dialog-dialog yang dilakukan, al-Qaraḍ̂âi selalu tampil bersama pemikiran-pemikiran progresif di berbagai bidang keilmuan Islam. Namun dari progresivitas pemikirannya tersebut selalu menampilkan spirit dakwah yang berorientasi pada kebangkitan peradaban umat, sebagaimana spirit yang selalu dimiliki oleh para pengusung semboyan al-Ṣậwah al-Islâmîyah (Kebangkitan Islam), utamanya dari kelompok al-Ikhwân al-Muslimûn. Hâamid al-Anșârî, salah seorang peneliti pemikiran al-Qaraḍ̂âi dari universitas Qatar, menyebutkan bahwa karakteristik pemikiran yang berbasis dakwah ini adalah muncul dari basis keilmuan yang mendidik al-Qaradâwî, yaitu yang lebih menonjol dipengaruhi oleh tiga tokoh Ikhwân al-Muslimîn; Ḥasan al-Bannâ, Muḥammad al-Ghazâlî, dan al-Bahy al-Hulî dan dengan tanpa mengabaikan pengaruh beberapa tokoh dari ulama al-Azhar. ${ }^{2}$

Di antara pemikiran al-Qara d̂âî yang berorientasi dakwah adalah gagasan tentang perlunya merumuskan konsep fiqh baru yang mampu menempatkan fiqh pada peran semestinya, yaitu sebagai sebuah aturan penegak keadilan sekaligus pranata sosial yang mampu menciptakan tata hukum yang berperadaban. Gagasan ini untuk pertama kali diangkat alQarậâî pada sebuah konferensi tahunan "Persatuan Pemuda Muslim Arab" (al-Mu'tamar al-Sanawî li Râbitah al-Shabâb al-Muslim al-'Arabì) di Amerika Utara Desember 1989. Dalam konferensi tersebut ia menyampaikan sebuah makalah berjudul "Awlawiyyât al-Ḥarakah alIslâmîyah fî al-'Uqûd al-Thalâthah al-Qâdimah” (Prioritas Gerakan Islam untuk Tiga Dasawarsa Mendatang). Melalui momentum itulah alQaradâwî mulai menawarkan pikiran barunya tentang fiqh yang berbasis "dakwah pembaruan" yang diistilahkan Fiqh al-Awlawiyyah (Fiqh Prioritas). Pada tahun berikutnya gagasan ini disajikan ke dalam sebuah buku berjudul Awlawiyyât al-Harakah al-Islâmîyah fî al-Marḅalah al-Qâdimah (Prioritas Gerakan Islam di Masa Depan), terbit pertama kali pada bulan

\footnotetext{
2 Hubungan keilmuan al-Qaradâwî dengan tiga tokoh yang disebutkan di atas lebih mendominasi dari pada keilmuan yang didapatkan dari instansi pendidikan al-Azhar, sebab bersama tiga tokoh tersebut ia lakukan secara privat yang berbeda dengan pendidikan di al-Azhar yang terbatas dilakukan mengikuti standar kurikulum, kecuali dari Muhammad 'Abd Allah Dâraz, Mạ̣mûd Shaltût, dan 'Abd al-Ḥalîm Mahmûd yang memiliki hubungan keilmuan yang khusus. Ibid., 20.
} 
April 1990. ${ }^{3}$ Kemudian pada September 1994, topik ini disajikan secara lebih sistematis dan tematik dalam bukunya FîFigh al-Awlawiyyât:Dirâsah Jadîdah fî Daw' al-Qur'ân wa al-Sunnah (Fiqh Prioritas: Telaah Baru dalam Perspektif al-Qur'ân dan Sunnah). ${ }^{4}$

Bagi al-Qaraḍ̂âî, Fiqh Prioritas bukan ide baru. Jauh sebelumnya ia sering menyinggung gagasan ini dengan istilah lain. Sebagaimana pengakuannya, buku-buku sebelum itu telah banyak mengangkat term serupa tetapi dengan istilah yang berbeda, seperti Fiqh Marâtib al-A'mâl (Fiqh Tata Urutan Amal), ${ }^{5}$ al-Ṣaḥwah al-Islâmîyah bayn al-Juhûd wa alTatarruf (Kebangkitan Islam antara Penyimpangan dan Hambatan) yang ditulis sejak tahun 1402 H./ 1982 M. dan diterbitkan oleh majalah alUmmah Qatar, ${ }^{6}$ dan buku al-Ṣahwah al-Islâmîyah wa Humûm al-Watan al'Arabî wa al-Islâmî (Kebangkitan Islam dan Ragam Problematika Negara Arab dan Islam) yang ditulis pada bulan Januari $1988 .^{7}$ Hal ini patut dimaklumi karena memang Fiqh Prioritas pada dasarnya terlahir dari sebuah proyek besar dakwah pembaruan Islam yang bertema al-Ṣạ̣wah al-Islâmîyah.

Menurut al-Qaraḍâwî, Fiqh Prioritas adalah sebuah pengetahuan tentang prinsip-prinsip keseimbangan yang penting untuk diterapkan dalam kehidupan menurut sudut pandang agama. ${ }^{8}$ Sedangkan dari sisi epistemologisnya, Fiqh Pioritas merupakan hasil elaborasi antara konsep tarî̀ maqâsidî́, yang dalam bahasa al-Qaradâwî disebut fiqh al-muwẫanât (fiqh pertimbangan), dengan konsep pengamatan atas kondisi realitas atau yang disebut dengan fiqh al-Wâqi' (fiqh realitas). ${ }^{9}$ Adapun muatan

3 Yûsuf al-Qaraḍ̂âî, Amlaniyyât al-Harakah al-Islâmîyah fi al-Marḅalah al-Qâdimah (t.t.: t.p., t.th.), 1-2.

4 Yûsuf al-Qaradâwî, Fî̀ Fiqh al-Awlawiyyât: Dirâsah Jadîdah fî̀ Daw' al-Qur'ân wa al-Sunnah (Kairo: Maktabah Wahbah, Cet. Ke-7, 2005), 6.

5 Ibid., 9.

6 Yûsuf al-Qaraḍ̂âî, al-Ṣạ̣wah al-Islâmîyah bayn al-Juḥ̂ud wa al-Tatarruf (Kairo: Dâr alShurûq, 2001), 7. Buku terbitan Dâr al-Shurûq Kairo ini terhitung sebagai cetakan kedua belas dari sekian kali percetakan buku ini.

7 Yûsuf al-Qaraḍ̂âî, al-Saḥwah al-Islâmîyah wa Humûm al-Watan al-'Arabî wa al-Islâmî (Kairo: Maktabah Wahbah, 1997), 173-174 dan 175.

8 al-Qaradâwî, Fî Fiqh al-Awlawiyyât, 5.

9 Aḥmad al-'Asâl, "al-Dâ’îyah al-Faqîh al-Shaykh Yûsuf al-Qaraḍ̂âi wa Masîrah Kham sîna 'Âman fî al-Da'wah ilâ Allah”, dalam dalam 'Abd al-Qâdir Maḥmûd al-Bakâr 
dari konsep Fiqh Pertimbangan sendiri adalah: pertama, memberikan pertimbangan antara berbagai kemaslahatan dan manfaat dari berbagai kebaikan yang disharî‘ahkan; kedua, memberikan pertimbangan antara berbagai bentuk kerusakan, madharat, dan kejahatan yang dilarang oleh agama; dan ketiga, memberikan pertimbangan antara maslahat dan kerusakan, antara kebaikan dan kejelekan apabila dua hal yang bertentangan ini bertemu satu sama lain. ${ }^{10}$ Dari konsep pertimbangan ini kemudian dianggap layak sebagai salah satu metode penetapan hukum Islam karena konsep ini berpijak kuat pada dalil-dalil tekstual dan maqâsìd sharî'ab. ${ }^{11}$

Prinsip-prinsip keseimbangan ini akan memberikan penilaian terhadap perkara-perkara, pemikiran dan perbuatan; mendahulukan sebagian perkara atas sebagian yang lain; antara yang patut didahulukan dan yang patut diakhirkan; perkara mana yang harus diletakkan dalam urutan pertama, dan perkara mana yang mesti ditempatkan pada urutan ke sekian pada anak tangga perintah Tuhan dan petunjuk Nabi.

\section{Definisi Fiqh Prioritas}

Fiqh Prioritas adalah terjemah dari istilah bahasa Arab Fiqh alAwlawiyyât. Secara etimologis, istilah ini merupakan gabungan dari dua suku kata, yaitu; al-fiqh dan al-Awlawiyyât. Kata al-figh secara etimologis berarti pemahaman atau ilmu. Sedangkan secara terminologi hukum Islam konvensional lebih diterjemahkan sebagai: "ilmu pengetahuan tentang hukum-hukum sharî'ah yang terkait dengan perbuatan-perbuatan mukallaf'. ${ }^{12}$

Dalam perkembangan dewasa ini, istilah "fiqh" oleh ahli-ahli hukum Islam kontemporer cenderung diterjemahkan menurut arti etimologinya; sebuah pengetahuan (pemahaman) dan yang lebih dispesifikasi lagi ke dalam "suatu pemahaman atas ajaran keislaman yang terkandung di

(ed.), Yûsuf al-Qaradâñ: Kalimât fî Takrimih wa Buḥ̂th fî Fikrih wa Fiqhih, Vol. 1 (Kairo: Dâr al-Salâm, 2004), 167.

10 al-Qaraḍ̂âî, Fî Fiqh al-Awlawiyyât, 25.

11 Adapun tendensi-tendensi keberlakuan konsep "fiqh pertimbangan" sebagai metode dalam penetapan hukum islam adalah sebagaimana tendensi-tendensi keberlakuan nilainilai maqậsid sebagai acuan ijtihad sebagaimana telah dijelaskan pada bab kedua.

12 Jamâl al-Dîn "Abd al-Rahîm al-Asnawî, "Nihạyat al-Sûl" dalam Muhammad b. alḤasan al-Badakhshî, Manâhij al-Uqûl, Vol. 1 (Beirut: Dâr al-Fikr, 2001), 19-20. 
dalam al-Qur'ân dan Sunnah secara umum". ${ }^{13}$ Sebagaimana Abû Hanîfah menamai buku kajiannya mengenai masalah akidah dengan sebutan fiqh al-Akbar, ${ }^{14}$ sehingga pelandasan hukum Islam tidak harus terbatasi pada sejumlah ayat yang dianggap sebagai ayat-ayat aḅkâm dalam teori konvensional, tetapi lebih disandarkan kepada prinsip-prinsip dan nilainilai universal al-Qur'ân dan Sunnah. Karena itu kita sering menjumpai istilah-istilah fiqh baru yang muncul dengan konsepsi pemikiran yang mengacu pada prinsip-prinsip dan nilai-nilai universal al-Qur'ân, seperti: fiqh al-ḥadârî (fiqh peradaban), fiqh al-wâqî‘ (fiqh realitas), fiqh al-aqalliyyât (fiqh minoritas), dan selainnya.

Sedangkan istilah al-awlawiyyât adalah bentuk jamak dari kata tunggal al-awlâ, yang tampil dalam bentuk ism al-tafḍ̂l (kata benda bermakna melebihkan). Secara etimologis, kata al-awlâ memiliki dua makna: pertama, lebih berhak atau lebih tepat; dan kedua, lebih dekat. Tetapi makna kedua pada dasarnya kembali kepada makna pertama. Ibn al-Manzûr menyebutkan suatu kalimat: fulân awlâ bi hâdhâ al-amr min fulân, artinya: si fulan lebih berhak atas suatu perkara. ${ }^{15}$ Adapun secara terminologis, istilah al-awlawiyyat belum pernah digunakan oleh ulama di masa klasik baik dari ahli-ahli linguistik maupun disiplin keilmuan Islam lainnya. ${ }^{16}$ Istilah al-awlawiyyat memang tergolong baru dan sering digunakan oleh para sarjana kontemporer dalam membincangkan terma dakwah pembaruan Islam.

Menurut penelitian Muhammad al-Wakîlî tentang penggunaan istilah al-Awlawiyyât di kalangan sarjanawan kontemporer dapat dibedakan menjadi tiga katagori: pertama, digunakan dalam persoalan pemikiran (alnazari), yakni pemikiran terhadap tata urutan amal-amal islami menurut tingkatan-tingkatannya. Kedua, digunakan dalam persoalan perbuatan

13 Yûsuf al-Qaraḍ̂âî, Taysîr al-Fiqh li al-Muslim al-Ma'ạsir fî Dạ’ al-Qur'ân wa al-Sunnah (Kairo: Maktabah Wahbah, 2004), 173.

14 Ṭâha Jâbir al-'Alwânî, Maqâșid al-Sharîah (Beirut: Dâr al-Hâdî, 2001), 64-65.

15 Jamâl al-Dîn Muḥammad b. Mukarram b. 'Alî b. al-Manẓûr, Lisân al-'Arab, 'Abd Allah 'Alî al-Kabîr (ed.) (Kairo: Dâr al-Ma'ârif, t.th.), 4921.

16 Istilah al-Awlawiyyât disebutkan pada beberapa literatur klasik namun dengan ungkapan kata tunggalnya, al-Awlâ, tetapi pendefinisian yang ada tidak keluar dari segi etimologi sebagaimana disebutkan di atas. Di antara ulama klasik yang menggunakan istilah ini adalah Ibn Hajar al-'Asqalânî, Fatḥ al-Bârî: Sharḥ Șahîh al-Bukhârî, 'Abd alQâdir Shaybah al-Ḥamd (ed.), Vol. 1 (Riyad: Maktabah al-Mulk al-Fahad al-Wạtanîyah, 1421), 96. 
aplikatif (al-'amalî). Ketiga, digunakan apabila terdapat kontradiksi antarhukum dalam hukum Islam dalam rangka memberikan suatu pertimbangan. ${ }^{17}$

Dari penggunaan istilah al-awlawiyyât di atas dapat kita pahami bahwa istilah ini cenderung digunakan untuk bidang kajian hukum Islam dan khususnya dalam ranah pengimplementasian hukum. Atas dasar ini, istilah al-awlawiyyat menurut penggunaan terminologinya dapat didefinisikan sebagai "bentuk-bentuk pengamalan sharî‘ah Islam yang memiliki skala prioritas tertentu atas dasar pertimbangan tertentu menurut ketentuan sharî‘ ${ }^{`}$ Islam itu sendiri”.

Al-Qaraḍ̂âi mendefinisikan fiqh al-awlawiyyât sebagai upaya meletakkan setiap sesuatu menurut peringkatnya, tidak mengakhirkan perkara yang seharusnya didahulukan atau mendahulukan perkara yang seharusnya diakhirkan, tidak meremehkan perkara yang besar dan tidak membesarkan perkara yang kecil". ${ }^{18}$

Definisi lain juga diungkapkan al-Qaraḍ̂âi dengan mengatakan "meletakkan segala sesuatu pada peringkatnya dengan adil, dari segi hukum, nilai, dan pelaksanaannya. Pekerjaan yang mula-mula dikerjakan harus didahulukan, berdasarkan penilaian sharî‘ ah yang benar, yang diberi petunjuk oleh cahaya wahyu, dan diterangi oleh akal. ${ }^{19}$

\section{Kaidah-kaidah Fiqh Prioritas}

Fiqh Prioritas merupakan suatu konsep pemikiran yang digunakan sebagai acuan dalam mengimplementasikan sharî‘ ah Islam, maka sudah semestinya memiliki seprangkat kaidah yang mengatur langkah-langkah cara-cara pengimplementasian tersebut. Al-Qara d̂âîi menjelaskan bahwa kaidah-kaidah yang dibangun dalam Fiqh Prioritas merupakan tampilan baru dari Fiqh Pertimbangan (figh al-muwâzanât) yang dikontekstualisir dengan realitas kehidupan (fiqh al-wâqi) kekinian. ${ }^{20}$

Peran terpenting yang dapat dilakukan oleh Fiqh Pertimbangan ialah: 1) memberikan pertimbangan antara berbagai kemaslahatan dan manfaat dari berbagai kebaikan yang disharî‘ahkan; 2) memberikan pertimbangan antara berbagai bentuk kerusakan, madharat, dan kejahatan yang dilarang

17 Muhammad al-Wakîlî, Figh al-Awlaniyyât Dirâsah fî al-Ḍawâbit (Hendon-Virginia: The International Institute of Islamic Thought, 1997), 13-14.

18 al-Qaradâwî, Awlawiyyât al-Harakah, 34.

19 al-Qaraḍ̂ûî, Fî Fiqh al-Awlawiyyât, 9.

20 al-Qaraḍ̂wî, Awlawiyyât al-Harakah, 20. 
oleh agama; dan 3) memberikan pertimbangan antara maslahat dan kerusakan, antara kebaikan dan kejelekan apabila dua hal yang bertentangan ini bertemu satu sama lain. ${ }^{21}$ Garis besar rumusan ini adalah sebagaimana yang pernah digariskan oleh Ibn Taymiyah dan al-'Izz b. 'Abd al-Salâm. ${ }^{22}$ Sementara dari ulama maqâssidiyyûn lain banyak kita jumpai pada topik-topik seputar tarjî̀ maqâsidî atau dalam penentuan urutan maqâsid (tartîb bayn al-maqậidi). ${ }^{23}$

Menurut al-Qaraḍ̂âî, Fiqh Pertimbangan yang pada gilirannya akan menjadi Fiqh Prioritas mengharuskan kita untuk: pertama, mendahulukan darûriyyât atas hâjïiyyât, apalagi terhadap taḥsinât, dan kedua, mendahulukan hâajjyyât atas taḥsinât dan kamâliyyât. Pada sisi yang lain, darûriyyât sendiri terbagi-bagi lagi menjadi beberapa bagian. Para ulama menyebutkan bahwa darûriyyât itu ada lima macam: agama, jiwa, keturunan, akal dan harta kekayaan. Sebagian ulama-seperti Shihâb al-Dîn al-Qarâfîmenambahkan darûriyyât yang keenam, yaitu kehormatan. ${ }^{24}$

Adapun kaidah-kaidah Fiqh Prioritas perspektif al-Qaraḍ̂uî secara terinci dapat kita amati pada tabel sebagai berikut: 25

\begin{tabular}{|c|c|c|}
\hline $\begin{array}{l}\text { Pertimbangan antar- } \\
\text { kemaslahatan }\end{array}$ & $\begin{array}{c}\text { Pertimbangan antar- } \\
\text { mafsadat }\end{array}$ & $\begin{array}{l}\text { Pertimbangan antara } \\
\text { maslahat dan } \\
\text { mafsadat bila terjadi } \\
\text { kontradiksi }\end{array}$ \\
\hline $\begin{array}{l}\text { Mendahulukan } \\
\text { kepentingan yang sudah } \\
\text { pasti atas kepentingan } \\
\text { yang baru diduga } \\
\text { adanya, atau masih } \\
\text { diragukan. } \\
\text { Mendahulukan } \\
\text { kepentingan besar dari } \\
\text { kepentingan kecil. } \\
\text { Mendahulukan }\end{array}$ & $\begin{array}{l}\text { Tidak ada bahaya dan } \\
\text { tidak boleh } \\
\text { membahayakan. } \\
\text { Suatu bahaya sedapat } \\
\text { mungkin harus } \\
\text { disingkirkan. } \\
\text { Suatu bahaya tidak } \\
\text { boleh disingkirkan } \\
\text { dengan bahaya yang } \\
\text { sepadan atau yang lebih }\end{array}$ & $\begin{array}{l}\text { Menolak kerusakan } \\
\text { harus didahulukan atas } \\
\text { pengambilan manfaat. } \\
\text { Kerusakan yang kecil } \\
\text { diampuni untuk } \\
\text { memperoleh, } \\
\text { kemaslahatan yang } \\
\text { lebih besar. } \\
\text { Kerusakan yang } \\
\text { bersifat sementara }\end{array}$ \\
\hline
\end{tabular}

21 al-Qaradîuî, Fî Fiqh al-Awlawiyyât, 25.

22 al-'Asâl, "al-Dâ'îyah al-Faqîh al-Shaykh Yûsuf al-Qaraḍ̂â̂̀”, 167.

23 Secara lebih luas dan lengkap tentang ragam bentuk tata urutan maqâsid di kalangan ulama maqâsidiyyûn, dapat dilihat dalam Jamâl al-Dîn 'Ațîyah, Nạ̣w Taf îl Maqậsid alSharîah (Damaskus: Dâr al-Fikr, 2001), 28-59.

24 al-Qarậâîî, Fî Fiqh al-Awlawiyyât, 25.

${ }^{25}$ Ibid., 25-28. 


\begin{tabular}{|l|l|l|}
\hline kepentingan sosial dari & besar. & diampuni demi \\
kepentingan individual. & Bahaya yang lebih & kemaslahatan yang \\
Mendahulukan & ringan, dibandingkan & sifatnya \\
kepentingan banyak & dengan bahaya lainnya & berkesinambungan. \\
dari kepentingan yang & yang mesti dipilih, & Kemaslahatan yang \\
sedikit. & boleh dilakukan. & sudah pasti tidak boleh \\
Mendahulukan & Bahaya yang lebih & ditinggalkan karena ada \\
kepentingan & ringan boleh dilakukan & kerusakan yang baru \\
berkesinambungan dari & untuk menolak bahaya & diduga adanya. \\
kepentingan insidental. & yang lebih besar. & \\
Mendahulukan & Bahaya yang bersifat & \\
kepentingan & khusus boleh dilakukan & \\
fundamental dari & untuk menolak bahaya & \\
kepentingan formalitas & yang sifatnya lebih luas & \\
dan tidak penting. & dan umum. & \\
Mendahulukan & & \\
kepentingan masa & & \\
depan yang kuat dari & & \\
kepentingan mutakhir & & \\
yang lemah. & & \\
\hline
\end{tabular}

Bagi al-Qaraḍ̂wi, kaidah-kaidah pertimbangan seperti di atas memiliki arti yang sangat penting dalam kehidupan nyata manusia, khususnya dalam masalah siyâsah sharîyah (politik hukum), karena ia merupakan landasan bagi pembinaan umat, yang pada gilirannya dapat dipandang sebagai prinsip prioritas. ${ }^{26}$

Dalam klarifikasi lebih lanjut, untuk dapat menurunkan kaidahkaidah prioritas pada tataran praktis hukum (tan₹îl al-aḅkâm), maka dibutuhkan penjelasan mengenai tiga cakupan persoalan: pertama, kaidahkaidah tentang tingaktan hukum dalam hukum Islam (al-fiqh bi marâtib ala'mâl); kedua, kaidah-kaidah tentang penyikapan terhadap realitas hukum (fiqh al-wâqi' li al-aḅkâm); dan ketiga, kaidah-kaidah tentang apabila terjadi kontradiksi antar-dalil atau pertimbangan antara ketetapan hukum dan realitas sosial. ${ }^{27}$

26 Ibid., 28.

27 Yûsuf al-Qaraḍ̂âî menjelaskan tentang tiga cakupan penurunan konsep Fiqh Prioritas pada tataran praktis hukum. Walaupun belum tersaji secara sistematis, namun perincian tersebut dianggap cukup mewakili bagi sejumlah tokoh lain yang memberikan perhatian terhadap terma Fiqh Prioritas seperti Muhammad al-Wakîlî dan Majdî alHilâlî. Ibid., 109-174. Bandingkan al-Wakîlî, Fiqh al-Awlaniyyât, 141-275. Majdî al-Hilâlî, 


\section{Perumusan Fiqh Prioritas Yûsuf al-Qaraḍâwî}

Ide-ide Yûsuf al-Qaraḍ̂âi tentang Fiqh Prioritas diproyeksikan sebagai langkah dakwah Islam dari sektor internal umat dengan melakukan pembinaan dan pencerahan terhadap pola pemahaman pemikiran keagamaan mereka. Menurut al-Qaradâwî, sasaran sektor internal ini lebih tepat dilakukan sebelum mengupayakan perbaikanperbaikan pada sektor eksternal peradaban Islam. Karena bagaimana pun juga, pemikiran manusia adalah faktor yang paling menentukan dalam pembangunan peradaban. ${ }^{28}$ Sedangkan langkah konkret yang dilakukan al-Qaraḍ̂wî dalam hal ini adalah dengan merumuskan sejumlah "fiqh baru" yang di antaranya berupa Fiqh Prioritas. ${ }^{29}$

Kehadiran Fiqh Prioritas adalah bagian dari proyek al-Ṣạwah alIslâmîyah. Garis besar pemikirannya tidak beranjak dari ideologi wasatîyah (moderatisme) sebagai identitas para pengusungnya, sebagaimana penelusuran sejumalah pengamat. ${ }^{30}$ Ideologi wasatîyah juga menjadi watak

Min Fiqh al-Awlawiyyâat fî al-Islâm (Kairo: Dâr al-Tawzî‘ wa al-Nashr al-Islâmîyah, 1994), 42-51.

28 Yûsuf al-Qaraḍ̂âî, Liqâât wa Muḥ̂awarât ḥawl Qậââa al-Islâm wa al-'Aṣr (Kairo: Maktabah Wahbah, 2001), 117-118.

29 Yûsuf al-Qaraḍ̂âî, al-Ṣạ̣wah al-Islâmîyah bayn al-Ikhtilâf al-Mashrû' wa al-Tafarruq alMadhmûm (Kairo: Dâr al-Shurûq, 2006), 6.

30 Muḥammad 'Imârah mencatat bahwa corak pemikiran yang dibawa oleh gerakan alSabiwah al-Islâmîyah periode kedua, yang dimulai sejak hadirnya tokoh-tokoh pembaru seperti Muḥammad 'Abduh dan Ḥasan al-Bannâ lebih menampilkan watak ideologi moderat bila dibandingkan dengan gerakan al-Sạ̣wah al-Islâmîyah periode pertama yang lebih menampakkan watak fundamentalisme dan anarkisme seperti yang dilakukan oleh kelompok Wahâbîyah, Sanûsîyah, dan Mahdîyah. Muḥammad 'Imârah, al-Sạ̣wah alIslâmîyah wa al-Taḥaddî al-Ḥậâî (Kairo: Dâr al-Shurûq, 1997), 11-12. Dalam buku alSaḥwah al-Islâmîyah fî̀ 'Uyûn al-Gharbîyah, 'Imârah memastikan bahwa upaya yang dilakukan gerakan pembaruan babak kedua ini merupakan penengah antara pemikiran fundamentalisme Islam dan liberalisme Barat. Muḥammad 'Imârah, al-Ṣạ̣wah alIslâmîyah fî̀ Uyûn Gharbîyah (Kairo: Nahḍat Miṣr, 1997), 36-37. Penilaian serupa juga dilontarkan oleh Anwar al-Jundî yang menyatakan bahwa motivasi utama dari gerakan al-Sạwah al-Islâmîyah adalah mengembalikan pola kehidupan dan pengamalan ajaran Islam di tengah umat dewasa ini sebagaimana potret Islam di masa Nabi, walaupun sikap-sikap yang sering ditampilkan oleh para pengusung ide ini terkesan untuk mengejar ketertinggalan terhadap kemajuan Barat dan menampilkan sikap apologetis dari ajaran-ajaran Islam dan Arabisme. Anwâr al-Jundî, Ițâr Islâmî li al-Ṣạ̣wah al-Islâmîyah (t.t.: Dâr al-Faḍîlah, 2000), 7. 
pemikiran al-Qaraḍ̂âî yang banyak dipengaruhi oleh beberapa tokoh modernis Mesir seperti Hasan al-Bannâ, al-Baghy al-Hụ̂lî, dan Muḥammad al-Ghazâlî. Hânî Muhammad TTâbî', seorang kritikus alQaraḍ̂âî asal Suriah, menuliskan ada empat kecenderungan pemikiran al-Qaraḍ̂wi yang moderat: pertama, ia mengelaborasi antara pemikiran ulama klasik dan kontemporer; kedua, ia menimbang antara hal-hal yang bersifat statis (thawâbit) dan elastis (mutaghayyirât); ketiga, ia menghindari kejumudan, kemunduran dan perpecahan dalam Islam; dan keempat, ia mengamati Islam secara universal. ${ }^{31}$ Empat kecenderungan ini selanjutnya diformulasikan ke dalam konsep pemikiran Islam yang tidak hanya mengacu kepada teks-teks parsial melainkan lebih mamadukannya dengan prinsip-prinsip universal Islam dan dimensi realitas tertentu. ${ }^{32}$

Berdasarkan identifikasi tersebut, dapat diamati bahwa pola pemikiran al-Qarậâ̂î yang berbasis maqậid sharîah sudah dimiliki sejak awal karir intelektualnya dan yang dipergunakan sebagai alat untuk memperjuangkan proyek "Kebangkitan Islam (al-Sạ̣wah al-Islâmîyah). Identifikasi ini sekaligus menepis anggapan bahwa pemikiran yang berbasis maqâsid baru bercokol dibenak al-Qaraḍ̂âi sejak bersentuhan dengan dunia Barat. ${ }^{33}$ Sebagaimana gaya pemikiran moderat dan berbasis maqâșid ini sudah tampak dari buku pertamanya al-Ḥalâl wa al-Ḥarâm fî alIslâm yang ditulis sebelum meraih gelar doctor dari Universitas al-Azhar. ${ }^{34}$

31 Hânî Muhammad Tâbî‘, "al-Shaykh al-Qaraḍ̂âî wa Manhajuh al-Wasaṭ̂yah alIslâmîyah”, dalam "Abd al-Qâdir Maḥmûd al-Bakâr (ed.), Yûsuf al-Qaradânri: Kalimât fî Takrîmih wa Buḥ̂uth fî Fikerih wa Fiqhih, Vol. 2 (Kairo: Dâr al-Salâm, 2004), 903.

32 Ibid., 904.

33 Ahmad Imam Mawardi, Figh Minoritas: Fiqh al-Aqalliyat dan Evolusi Maqasid al-Syari'ah dari Konsep ke Pendekartan (Yogyakarta: LKiS, 2010), 118.

34 Menurut hasil identifikasi Hibbah Ra'ûf 'Azzat, salah satu dosen ilmu ekonomi di Universitas Kairo, karakter pemikiran al-Qaraḍ̂âî yang moderat sudah terbaca sejak penulisan buku pertamanya al-Ḥalâl wa al-Ḥarâm fî̀ al-Islâm. Dalam kata pengantar cetakan pertama buku itu, tahun 1960, al-Qaraḍ̂âî menglasifikasi kecenderungan pemikiran Islam ke dalam tiga tipe, antara lain: pertama, pemikiran yang cenderung kepada gaya pemikiran Barat; kedua, pemikiran yang cenderung kepada kebekuan pemikiran dan hanya menafsir secara terkstual; dan ketiga, pemikiran yang mampu mengontekstualisir makna teks dengan pergeseran ruang dan zaman. Tipe ketiga adalah yang dipilih oleh al-Qarậâîi dan yang akan diupayakan dalam penulisan bukunya tersebut. Hibbah Ra'ûf 'Azzat, “al-Mar'ah wa Tayyâr al-Wasaṭiyah al-Islâmîyah”, dalam 'Abd al-Qâdir Maḥmûd al-Bakâr (ed.), Yûsuf al-Qaradânî: Kalimât fî Takrîmih wa Buḥ̂th fî̀ Fikerih wa Fiqhih, Vol. 2 (Kairo: Dâr al-Salâm, 2004), 919. Yûsuf al-Qaraḍâwî, al-Ḥalâl wa 
Moderasi pemikiran al-Qaraḍ̂wî juga tampak pada rumusan Fiqh Prioritas sebagai salah satu instrumen pemikiran maqâșid-nya. AlQaraḍ̂âi tidak mengonstruk prinsip-prinsip prioritas atas dasar pertimbangan rasional secara sepihak, melainkan dengan tetap memperhatikan teks-teks partikular. ${ }^{35}$ Dalam aplikasi konsep, ia tetap membedakan antara perkara-perkara yang bersifat qat t $^{\prime}$ (tegas dan statis) yang harus dijalankan secara dogmatis dan yang bersifat zannî (samar dan asumtif) yang boleh dirasionalisir sekaligus direlevansikan menurut konteks tertentu. ${ }^{36}$ Untuk mengetahui skala prioritas tertentu dalam sharî‘ ah Islam adalah dilakukan dengan dua cara: pertama, skala prioritas yang diketahui melalui teks-teks keislaman (tanșiss al-awlawî); dan kedua, skala prioritas yang diketahui melalui ijtihad rasional (ijtihâd al-awlawî).

Sikap membedakan antara hal-hal yang bersifat qat' aplikasi ijtihad merupakan konsekuensi dari sebuah prinsip maqâsid bahwa asal hukum segala persoalan selain ibadah dan timbangan sharî‘ $a h$ adalah memiliki alasan ('illah), tujuan, dan hikmah tertentu. ${ }^{37}$ Prinsip ini adalah sebuah pemahaman yang cenderung mengikuti mazhab pemikiran maqâșid al-Shâtibî, ${ }^{38}$ dan juga termasuk yang diadopsi oleh Ibn 'Âshûr. ${ }^{39}$ Ini bukan satu-satunya pendapat dalam Islam atau telah menjadi

al-Ḥarâm fî al-Islâm (Kairo: Maktabah Wahbah, Cet. Ke-29, 2007), 10-11. Sementara itu, menurut pembacaan 'Alî Muhy al-Dîn al-Qurhudânî, kecenderungan pemikiran yang berbasis maqậid sharîah al-Qaraḍâwî sudah teridentifikasi semenjak penulisan buku Fiqh al-Zakâh. "Alî Muḥy al-Dîn al-Qurhudâni, "Fiqh al-Qaradâwîi fî al-Zakâh", dalam 'Abd al-Qâdir Maḥmûd al-Bakâr (ed.), Yûsuf al-Qaradânî: Kalimât fî Takrîmih wa Buhûth fî Fikrih wa Fiqhih, Vol. 2 (Kairo: Dâr al-Salâm, 2004), 599-600.

35 al-Qaradâwî, Fî Fiqh al-Awlawiyyât, 33.

36 Ibid., 64-65.

37 Menurut al-Qaradâwî, hukum-hukum sharî‘ah secara global memiliki alasan, tujuan, serta hikmah tertentu di balik setiap ketetapan hukumnya. Namun hal itu tidak berlaku untuk sebagian persoalan ibadah mạ̣dah. Walaupun memiliki tujuan tetapi ada yang tidak bisa dimengerti secara pasti. al-Qaraḍ̂âî, Fî Fiqh al-Awlawiyyât, 32.

38 Abû Ishâaq al-Shâtịîi, al-Muwâfaqât fî Ușûl al-Sharîah, Vol. 1, ed.: 'Abd Allah Darrâz (Kairo: Maktabah Tawfiqîyah, t.th.), 327 dan 339.

39 Muhammad Tâhir b. 'Âshûr, Maqâsid al-Sharî'ah al-Islâmîyah (Kairo: Dâr al-Salâm, Cet. Ke-2, 2007), 41 dan 45. 
kesepakatan semua ulama, melainkan sebagai pendapat yang relatif moderat dari tiga silang pendapat yang terjadi di kalangan ulama $u s \hat{u} l^{40}$ Hal terpenting yang patut disorot dari konsep Fiqh Prioritas alQarậâîi adalah mengenai tata urutan nilai-nilai maqâsid yang dijadikan sebagai acuan pemikiran prioritasnya. Al-Qaraḍ̂wî menyebutkan tiga kategori tingkatan maqâsid, yaitu: 1) darûriyyât (primer); 2) hâajiyyât (sekunder); dan 3) taḥsiniyyât (sekunder). ${ }^{41}$ Al-Qaraḍâwî lanjut menguraikan:

"Yang dimaksudkan dengan darûriyyât ialah sesuatu yang kita tidak bisa hidup kecuali dengannya; dan hâjyyyat ialah kehidupan memungkinkan tanpa dia, tetapi kehidupan itu mengalami kesulitan dan kesusahan; dan tahsinizyat ialah sesuatu yang dipergunakan untuk menghias dan mempercantik kehidupan, atau yang seringkali kita sebut dengan kamâliyyât (pelengkap)". ${ }^{42}$

Tiga kategori tingkatan maqâsid di atas adalah klasifikasi yang biasa dipakai oleh jumbûr ulama terutama dari al-Ghazâlî ${ }^{43}$ dan al-Shâtibî. ${ }^{44}$ Kecenderungan al-Qaraḍ̂âi untuk lebih memilih pandangan jumbûr ulama ini merupakan bentuk dari sikap moderatnya untuk menghindari silang pendapat berkelanjutan yang dapat mengarah pada disintegrasi umat. Namun pada sisi lain, tiga kategori tingkatan tersebut masih menyisahkan dua persoalan, yaitu terdapatnya perkara-perkara yang berada pada tingkatan di atas kategori darûriyyât dan di bawah kategori taḥsiniyyât yang belum terakomodir oleh klasifikasi jumbûr ulama di atas.

40 Aḥmad al-Raysûnî menyebutkan ada tiga pendapat tentang "apakah hukum-hukum sharî́ah Islam memiliki illah, tujuan, dan hikmah? Pertama, pendapat yang menegasikan secara tegas adanya 'illah, tujuan, dan hikmah tertentu dalam hukum Islam yang dapat diketahui oleh akal pikiran manusia, yaitu dari jumbûr ulama, mazhab Shâfîîyah serta yang dipilih oleh al-Râzî. Kedua, pendapat yang menerima tentang adanya 'illah, tujuan, dan hikmah tertentu dari penetapan hukum sharî‘, yaitu dari mazhab Hạafiyah. Ketiga, pendapat yang membedakan antara persoalan hukum bidang ibadah dan ukuran yang tidak bisa diberikan kepastian mengenai 'illah, tujuan, dan hikmahnya dengan persoalan hukum bidang mu'âmalah dan 'adah yang memiliki 'illah, tujuan dan hikmah tertentu, yaitu pendapat mazhab Mâlikîyah dan Hanâbilah. Lihat Aḥmad al-Raysûnî, Nažarîyat al-Maqâsid 'ind al-Shâtibî (Hemdon-Virginia: The International Institute of Islamic Thought, Cet. Ke-4, 1995), 207-238.

41 al-Qaraḍâwî, Fî Fiqh al-Awlawiyyât, 25; Yûsuf al-Qaraḍ̂âî, Dirâsah fî Fiqh Maqâsid alSharîah (Kairo: Dâr al-Shurûq, 2006), 29.

42 al-Qaraḍ̂âî, Fî̀ Fiqh al-Awlaniyyât, 25.

43 Abû Hâamid al-Ghazâlî, al-Muṣtasfâ min Tlm al-Uṣ̂ul, ed. Muhammad 'Abd al-Salâm 'Abd al-Shâfî (Beirut: Dâr al-Kutub al-'Ilmîyah, 2000), 174-175.

44 al-Shâtibî, al-Muwâfaqât, Vol. 1, 6-9. 
Persoalan ini sempat disinggung 'Alî Jum'ah dalam pembahasan seminar di Universitas al-Azhar, ia mengangkat pernyataan Jalâl al-Dîn al-Suyûțî tentang ada sebagian ulama-yaitu al-Zarkashî, menurut keterangan kitab al-Mawâhib al-Sunnîyab — yang membagi tingkatan maqâșid ke dalam lima kategori, antara lain: (1) darûrah, (2) ḅajah, (3) manfa'ah, (4) zînah, dan (5) fudûl. ${ }^{45}$ Kategorisasi nilai-nilai maqâsid pada tingkatan-tingkatannya adalah ditentukan oleh kaca pandang personal ulama terhadap ketetapan-ketetapan sharî‘ah yang bersifat otoritatif. Selain itu posisi mukallaf dalam mengamalkan sharî'ah cenderung tidak sama dari setiap ruang dan waktu, sehingga kategorisasi yang muncul cukup bervariasi. Namun hal penting yang patut diperhatikan adalah memberikan ketentuan konkret mengenai batasan terendah untuk tingkatan darûriyyât dan batasan tertinggi untuk tingkatan hâajiyyât. Sebab, hal-hal yang tergolong darûriyyât adalah yang paling urgen dalam agama, yang tidak mengalami pergeseran dan penghapusan pada setiap perubahan zaman dan ruang. ${ }^{46}$

Oleh karena persoalan darûriyyât memiliki urgensi yang cukup tinggi sehingga hal itu banyak diberi perhatian besar oleh para ulama karena

45 Dikutip dari 'Ațîyah, Naḥw Taf' $̂$ l, 55-56. Adapun penjelasan varian batasannya sebagai berikut: (1) Darûrah. Apabila tidak melakukan perkara yang dilarang/diharamkan akan menjadikannya jatuh pada kehancuran, sehingga kategori ini membolehkan untuk melakukan hal yang haram. (Kategori ini berada di atas tingkatan darûriyyât dalam perspektif jumbûr ulama). (2) Hâjah. Apabila tidak dilakukan perkara tersebut, maka tetap tidak jatuh pada kehancuran tetapi seseorang akan mengalami kesulitan dan kesusahan. Kategori ini tidak bisa menghalakan hal yang haram. (Kategori ini berada pada tingkatan darûriyyât dalam perspektif jumbûr ulama). (3) Manfáah. Seperti roti gandum, daging sapi dan makanan berat lainnya. (Kategori ini berada pada tingkatan ḅâjiyyât dalam perspektif jumbûr ulama). (4) Zînah. Seperti gula, manisan, pakaian dari bahan campuran katun dan sutra. (Kategori ini berada pada tingkatan taḥininyyât dalam perspektif jumbûr ulama). (5) Fudûl. Seperti mengonsumsi makanan yang kemungkinan hukumnya halal atau haram. (Kategori ini berada di bawah tingkatan tahsiniyyât dalam perspektif jumbûr ulama).

46 Shihâb al-Dîn al-Qarâfî, sebagaimana yang dikutip oleh al-Zarkashî, menyebutkan bahwa: "Pe-naskh-an terhadap hukum-hukum sharîah lama dengan hukum-hukum sharîa baru tidaklah secara mutlak, sebab prinsip-prinsip akidah tidak terhapus. Demikian halnya dengan pemeliharaan terhadap lima prinsip universal (kulliyyât alKhams), tetapi naskh itu terjadi pada sebagian hukum-hukum cabang. Badr al-Dîn alZarkashî, al-Baḥr al-Muḥ̂t, Vol. 4 (Kuwait: Wizârat al-Awqâf wa al-Shu'ûn al-Islâmîyah, 1988), 75. 
persoalan-persoalan yang terkandung di dalamnya. Termasuk perhatian al-Qaraḍ̂âi dalam masalah ini yang mengurutkan tingkatan darûriyyât ke dalam enam tingkatan: (1) agama, (2) jiwa, (3) akal, (4) keturunan, (5) harta, dan (6) kehormatan. ${ }^{47}$ Dalam timbangan prioritas al-Qaradâwî menyatakan darûriyyât harus didahulukan daripada hâajiyyât, apalagi terhadap taḥsiniyyât. Kemudian darûriyyât dengan enam tingkatannya harus ditempatkan secara hierarkis. Ia menyebutkan:

"Agama merupakan bagian pertama dan terpenting dari kategori darûriyyât. Ia harus didahulukan dari berbagai macam darûriyyât. Yang lain, sampai kepada jiwa manusia. Pun jiwa harus diutamakan dari darûriyyât yang lain di bawahnya". ${ }^{48}$

Apabila enam darûriyyât tersebut di atas harus diurutkan secara hierarkis, oleh al-Qaraḍ̂âî, tetapi dalam bukunya yang lain disebutkan dengan urutan yang berbeda, yaitu: (1) agama, (2) jiwa, (3) keturunan, (4) akal, (5) harta, dan (6) kehormatan. ${ }^{49}$ Di sini tampak janggal karena pada satu kesempatan al-Qaraḍ̂wî menempatkan "akal" lebih utama daripada "keturunan", namun pada kesempatan lain justru sebaliknya. Perbedaan ini apabila diamati dari wacana pemikiran maqâsid sharîa tidak menunjukkan kekeliruan atau kejanggalan pemikiran. Sebab dari ulama maqâșidiyyûn sendiri tidak terlalu memperhatian urutan-urutannya secara hierarkis, termasuk al-Ghazâlî dan al-Shâtibî. Tetapi pada sisi yang lain, al-Qaradâuî dan beberapa ulama lainnya cenderung menempatkan persoalan agama pada urutan pertama di antara darûriyyât yang lain. Alasannya, persoalan agama adalah yang paling urgen, bersifat otoritatif dan tolok ukur kemaslahatan yang hanya diketahui oleh Shâri'.

Disadari ataupun tidak, pengurutan maqâsid darûriyyât dengan menempatkan agama pada urutan pertama adalah produk pikiran-pikiran ulama yang tidak bebas kritik. Menurut para ahli, al-Juwaynî (w. 478 H.) adalah alim awal yang membuat hierarki tata-urutan maqậid ḍarûriyyât

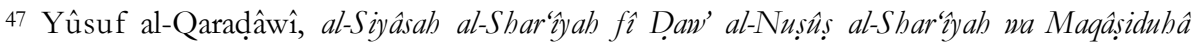
(Kairo: Maktabah Wahbah, 1998), 311-312. Bandingkan al-Qaraḍ̂âî, Fî̀ Fiqh alAwlawiyyât, 25.

48 al-Qaraḍ̂âî, Fî Fiqh al-Awlawiyyât, 25.

49 Ibid., 25.
} 
yang kemudian diwariskan kepada muridnya al-Ghazâlî. ${ }^{50}$ Untuk itu, sangat wajar jika ulama lain memiliki pandangan yang berbeda.

Dalam wacana pemikiran maqâsid, beberapa ulama tidak melazimkan agama ditempatkan pada urutan pertama, sebab persoalan agama lebih memuat hak dan kewajiban yang berhubungan dengan Allah yang lebih mengedepankan toleransi dan kemampuan personal (istitâ' $a$ b). Sementara persoalan selain agama, terutama persoalan jiwa, lebih terkait pada hak dan kewajiban sesama manusia yang harus diselesaikan. ${ }^{51}$ Adapun tata urutan maqâșid d̦arûriyyât dari para ulama yang tidak mengharuskan agama pada urutan pertama adalah sebagai berikut:

\begin{tabular}{|c|c|}
\hline Nama Ulama & Tata Urutan Maqâsid Darûriyyât \\
\hline 1. Al-Râzî (606 H.) & $\begin{array}{l}\text { Model I: Jiwa } \rightarrow \text { harta } \rightarrow \text { keturunan } \rightarrow \\
\text { agama } \rightarrow \text { akal. }{ }^{52} \\
\text { Model II: Jiwa } \rightarrow \text { akal } \rightarrow \text { agama } \rightarrow \text { harta } \rightarrow \\
\text { keturunan. }\end{array}$ \\
\hline $\begin{array}{l}\text { 2. Shihâb al-Dîn al-Qarâfî } \\
\text { (684 H.) }\end{array}$ & $\begin{array}{l}\text { Jiwa } \rightarrow \text { agama } \rightarrow \text { keturunan } \rightarrow \text { akal } \rightarrow \text { harta } \\
\rightarrow \text { kehormatan. }{ }^{54}\end{array}$ \\
\hline $\begin{array}{l}\text { 3. Nâsir al-Dîn al- } \\
\text { Bayḍâwî }(685 \text { H.) }\end{array}$ & 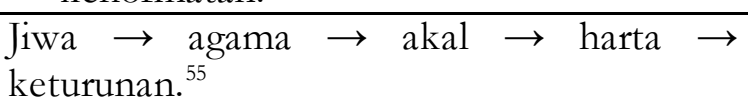 \\
\hline 4. Ibn Taymîah (738 H.) & $\begin{array}{l}\text { Jiwa } \rightarrow \text { harta } \rightarrow \text { kehormatan } \rightarrow \text { akal } \rightarrow \\
\text { agama. }^{56}\end{array}$ \\
\hline $\begin{array}{l}\text { 5. Badr al-Dîn al- } \\
\text { Zarkashî (793 H.) }\end{array}$ & $\begin{array}{l}\text { Jiwa } \rightarrow \text { harta } \rightarrow \text { keturunan } \rightarrow \text { agama } \rightarrow \\
\text { akal. }\end{array}$ \\
\hline
\end{tabular}

50 Muhammad al-Dasûqî, "Manâhij Tadrîs fî Fiqh al-Islâmî" dalam Mawsĥ' at al-Tashrî alIslâmî (Kairo: al-Majlis al-A'lâ li al-Shu'ûn al-Islâmîyah, Cet. Ke-2, 2009), 700.

51 'Ațîyah, Naḥw Taf'îl, 35.

52 Fakhr al-Dîn al-Râzî, al-Mahṣ̂ul fî Tlm Uș̂ll al-Figh, Vol. 2 (Riyad: Jâmi'at al-Imâm Muḥammad b. Su'ûd, t.th.), 220.

53 Ibid., Vol. 2, 612.

54 Shihâb al-Dîn al-Qarâfî, Sharḥ Tanqîh al-Fuṣull, ed.: Ṣidqî Jamîl al-'Ațâr (Beirut: Dâr alFikr, 2004), 351.

55 Naṣir al-Dîn al-Bayḍ̂âî, "Minhâj al-Wuṣûl fî 'Ilm al-Uṣûl", dalam Muhamamad b. Ḥasan al-Badakhshî, Manâhij al-'Uqûl fî̀ 'Im al-Uṣûl, Vol. 3 (Beirut: Dâr al-Fikr, 2001), 793.

56 Taqiy al-Dîn Aḥmad b. Taymîyah, Majmû́ 'at al-Fatâwâ, ed.: 'Abd al-Rahmâ al-Najadîr, Vol. 1 (Riyad: al-Malik Fahad b. 'Abd al-'Azîz Ali Su'ûd, t.th.), 343.

57 al-Zarkashî, al-Bạ̣r al-Muḅ̂t, Vol. 5, 208-213. 
Persoalan tata urutan maqâsid memang kontroversial di kalangan ulama. Mereka cenderung berbeda dalam menentukan skala prioritas tertentu terhadap nilai-nilai universal sharî'ah-baik dalam memberikan batasan-batasan tentang darûriyyât, ḥâjizyyât, taḅsiniyyât, maupun perincian untuk tata urutan darûriyyât itu sendiri-yang ditentukan oleh ketajaman daya analisa yang mereka lakukan terhadap dalil-dalil sharî‘ah dan hukum-hukum partikular. ${ }^{58}$

Penentuan tata urutan maqâsid juga dipengaruhi oleh faktor eksternal berupa kondisi realitas sosial yang terjadi di zaman mereka masingmasing. Seperti prioritas pemeliharaan jiwa dalam posisi tertinggi pada tingkat darûriyyât oleh Ibn Taymîyah, sebagaimana identifikasi sejarah Muhammad 'Imârah, adalah dilatari oleh kondisi sosial umat Islam di masa itu yang terpuruk di bawah penjajahan bangsa Tatar. Ini yang menyebabkan perhatian Ibn Taymîyah lebih terarah pada keselamatan kaum Muslim dan demi kelangsungan kehidupan mereka, sehingga langkah prioritas yang diambil lebih kepada pemeliharaan jiwa daripada darûriyyat yang lainnya. Pertimbangan prioritas tertentu juga menjadi perhatian al-Qaraḍ̂âî. Jika langkah prioritas yang diambil adalah dengan menempatkan pemeliharaan agama pada urutan darûriyyât pertama, maka hal ini patut dimaklumi karena visi yang diemban dari gagasan Fiqh Prioritasnya adalah mengembalikan pola peribadatan dan keagamaan umat Islam secara lebih seimbang.

\section{Fiqh Prioritas sebagai Sistem: Elaborasi antara Fiqh, Realitas, dan Maqâșid Sharîah}

Setiap umat beragama meyakini bahwa segala Perbuatan Tuhan mempunyai tujuan tertentu, hingga mustahil jika Tuhan menciptakan sesuatu sia-sia. Termasuk penciptaan manusia di bumi yang dipenuhi berbagai kebutuhannya guna dapat melangsungkan kehidupan hingga menemui ajalnya. Dalam melangsungkan kehidupan, manusia membutuhkan tuntunan agar selama perjalanan hidupnya tidak mengalami kesia-siaan, berjalan harmonis bersama manusia yang lain, serta dapat merasakan kesejahteraan dan kebahagiaan. Untuk itu, Tuhan

\footnotetext{
58 al-Raysûnî, Nažarîyat al-Maqậid, 310.
} 
menggariskan seperangkat aturan kehidupan, berupa ajaran sharî‘ ah, yang juga dalam rangka memenuhi kebutuhan manusia itu sendiri. ${ }^{59}$

Fiqh Islam adalah suatu disiplin ilmu yang memuat aturan-aturan hukum yang dipahami dari sumber-sumber kewahyuan, sedangkan secara teoretis ia senantiasa memiliki keterkaitan yang erat dengan konteks kehidupan yang ditetapkan hukumnya, sebagaimana juga berkaitan dengan tujuan hukum yang dibawanya, yaitu berupa perwujudan kemaslahatan. ${ }^{60}$ Untuk itu, karakteristik yang paling menonjol yang dimiliki oleh fiqh Islam adalah "berpijak kuat pada asas-asas ketuhanan yang bersinergi dengan konteks kehidupan yang terus berdinamika". ${ }^{61}$

Dalam sejarahnya, fiqh berkembang pesat bersamaan dengan perkembangan disiplin-disiplin ilmu Islam lainnya sejak permulaan abad kedua Hijriyah, atau yang dikenal sebagai periode kodifikasi dalam sejarah Islam. ${ }^{62}$ Perkembangan ilmu fiqh pada puncaknya adalah saat berada di tangan para imam mazhab hingga abad ketiga Hijrîyah. Di tangan mereka fiqh dianggap telah mencapai kesempurnaan dengan kelengkapan isi dan cakupan serta telah disertai dengan teori-teori ijtihad (usûul al-fiqh) yang mendetail. Kemajuan ini berdampak negatif terhadap perjalanan fiqh di masa-masa setelahnya. Sebuah ikon yang berbunyi "pintu ijtihad sudah tertutup" menjadi slogan dari setiap perbincangan para ulama pengikut mazhab. Akibatnya, fiqh mengalami stagnansi pemikiran hingga pada pertengahan abd ketujuh Hijrîyah yang dikenal sebagai 'așr al-jumûd wa al-taqlîd (masa kejumudan dan ketaklidan). ${ }^{63}$

59 Muḥammad Yûsuf Mûsâ, al-Islâm wa Hâjah al-Insânîyah ilayb (Kairo: al-Majlis al-A'lâ li Shu'ûn al-Islâmîyah, 2003), 12-13.

60 Aḥmad al-Raysûnî dan Jamâl Bârût, al-Ijtihâd bayn al-Naṣs wa al-Wâqi“ wa al-Mașlaḥah (Damaskus: Dâr al-Fikr, 2000), 29.

61 Beberapa pakar hukum Islam, semisal Yûsuf al-Qaraḍ̂âî, memberikan beberapa kesimpulan perihal karakteristik yang dimiliki oleh Fiqh Islam, yaitu: 1) berpijak pada asas Ketuhanan; 2) memiliki spirit religius; 3) bersinergi dengan tabiat kemanusiaan; 4) memiiki jangkauan luas dan terperind; 5) memuat nilai-nilai etika; 6) mendunia; 7) tematik; 8) moderatis; 9) mempertimbangkan kepentingan individu dan sosial; 10) memiliki prinsip-prinsip universal; dan 11) memiliki kemampuan untuk berkembang dan memperbarui. Yûsuf al-Qaraḍ̂âî, al-Fiqh al-Islâmî bayn al-Asâlah wa al-Tajdîd (Kairo: Maktabah Wahbah, 1999), 7-22.

62 Muḥammad al-Khuḍarî Bik, Târîkh al-Tashrî' al-Islâmî, ed.: Maḥmûd 'Abbâs (Kairo: Mu'assasat al-Mukhtâr, 2007), 105 dan 108.

63 Para ahli mencatat bahwa masa stagnansi pemikiran fiqh adalah dimulai sejak pertengahan abad keempat sampai pada pertengahan abad ketujuh Hijrîyah, tepatnya di 
Problematika hukum mulai bermunculan sejak dirasakan bahwa sudah tidak ada lagi hubungan erat antara fiqh, realitas, dan maqâșid sharîhah yang disebabkan oleh tiga hal, antara lain: 1) fiqh-fiqh yang terkodifikasi dibuat dalam konteks negara-negara Muslim di Timur Tengah, sementara Islam berkembang jauh melampui batas teritorial wilayah Timur Tengah; 2) produk figh-fiqh merupakan pendapat dan fatwa hukum yang dibuat di era klasik di mana para fuqahâ' tidak memiliki gambaran tentang konteks kehidupan masa modern; dan 3) adanya keterputusan maqâsid al-sharî́ah dengan ketentuan fiqh akibat diaplikasikannya fiqh produk klasik pada konteks modern yang berbeda.

Kekakuan hukum-hukum dalam fiqh menjadi perdebatan yang terus aktual. Ia tidak lagi bersifat fleksibel dan elastis; sebagaimana yang dipaparkan dalam teori-teori yang ada, termasuk juga ikon bahwa hukum Islam selalu "relevan di setiap ruang dan waktu" sulit dibuktikan. Dalam rangka menampilkan kembali nuansa fiqh yang fleksibel, elastis dan responsif terhadap perubahan sosial; seperti yang diprogramkan oleh dari pemerintah Turki Otoman tahun 1286 dengan mengeluarkan majalah alAḥkâm al-'Adalîyah. ${ }^{64}$ Upaya pembaruan pertama memang berkepentingan untuk melegalkan fiqh sebagai kitab perundangan negara, namun selanjutnya memberikan spirit bagi sejumlah ahli-ahli hukum Islam kontemporer untuk melakukan rekonstruksi fiqh. ${ }^{65}$

Jamâl al-Dîn 'Ațîyah mencatat bahwa upaya-upaya rekonstruksi fiqh pada tahap berikutnya tidak sekadar secara esensial melainkan juga format penulisan yang ditampilkan secara tematik dan adanya kecenderungan untuk mengelaborasi dengan nilai-nilai hikmah dan maqâsid sharîah. ${ }^{66}$ Tampilan format fiqh baru menjadi tuntutan di era

masa tumbangnya kedaulatan kaum Muslimin di kota Baghdad tahun $656 \mathrm{H}$. Lihat 'Alî Jum'ah Muhạmmad, al-Madkhal ilâ Dirâsat al-Madhâhib al-Fiqhîyah (Kairo: Dâr al-Salâm, 2004), 355.

64 'Abd al-Wahhâb Khalâf, Khulâsah Târîkh al-Tashrî' al-Islâmî (Kuwait: Dâr al-Qalam, 1996), 103-15.

65 Mannâ' al-Qattân, Târîkh al-Tashrî‘ al-Islâmî: al-Tashrî wa al-Fiqh (Riyad: Maktabat alMa'ârif, Cet. Ke-2, 1996), 402.

66 Jamâl al-Dîn 'Ațiyah mencatat ada beberapa karakteristik dalam format penyajian fiqh baru dari para akademisi kontemporer, yaitu dengan mengelaborasi fiqh dengan sejumlah nilai seperti: 1) sharî‘ah dan filsafat sejarah, 2) nilai-nilai keimanan, 3) nilai-nilai etika, 4) nilai-nilai maqậsid dan prinsip-prinsip universal, 5) kewajiban dan hak asasi manusia, 6) sinkronisasi antara fiqh dengan IPTEK, 7) nilai-nilai dakwah dan syiar 
kontemporer guna mewujudkan peran dan fungsi fiqh itu sendiri, yakni fiqh selain bertindak sebagai kitab ketentuan hukum ia juga harus mampu menanamkan kesadaran hukum bagi mukallaf dengan memberikan pemahaman nilai-nilai hikmah dan tujuan sharî‘ah. Di antara beberapa buku yang dianggap mewakili antara lain: al-Islâm 'Aqîdah wa Sharî'ah karya Maḥmûd Shaltût, al-Tashrî' al-Jinâ'î al-Islâmî karya 'Abd al-Qâdir 'Awdah, al-Mas'ûlîyah al-Jinâ'îyah karya Muhammad Kamâl al-Dîn Imâm, serta yang lainnya. ${ }^{67}$

Kehadiran format fiqh baru yang berorientasi untuk menanamkan kesadaran hukum adalah yang juga menjadi tujuan dari perumusan figh prioritas sebagaimana yang telah dikemukakan sebelumnya. Lebih dari itu, fiqh prioritas juga dimaksudkan sebagai media dakwah untuk mengantarkan umat Islam menuju iklim peradaban yang lebih baik. Hal ini diupayakan karena dengan melihat bahwa fiqh konvensional yang ada selama ini hanya bertindak sebagai kitab hukum yang menutup mata terhadap keberlangsungan masa depan umat dengan multi problematika yang tengah mereka hadapi.

Demi tercapainya tujuan sharî'ah Islam, sebagaimana juga yang telah kita amati bersama, bahwa fiqh prioritas adalah suatu rumusan yang mengaplikasikan nilai-nilai maqâșid pada tataran praktis hukum dengan cara mengaktualisir tata-urutan maqâșid dengan realitas empirik yang terjadi di tengah kehidupan. Orientasi fiqh yang berbasis dakwah ini di antaranya ditampilkan dalam beberapa kajian fiqh, seperti: Awlawiyyât alHarakah al-Islâmîyah dan Fî Fiqh al-Awlawiyyât fî al-Islâm karya alQaraḍ̂wî, Awlawiyyât al-'Amal al-Islâmî karya 'Abd al-Raḥmân 'Abd alKhâliq, ${ }^{68}$ Awlawiyyât al-Qânûn al-Siyâsŷjah dan Awlawiyyât al-Fârûq 'UmaralSiyâsîyah karya Ghâlib 'Abd al-Kâfî, ${ }^{69}$ Ahammîyat al-jihâdfî Nashr al-Da'wah

Islam, dan sembilan hal lainnya. Lihat lebih jauh Jamâl al-Dîn 'Ațîyah dan Wahbah alZuhaylî, al-Tajdîd al-Fiqh al-Islâmî (Damaskus: Dâr al-Fikr, 2000), 75-76.

67 Ibid., 116-117. Jamâl 'Aț̂yah juga mengapresiasi buku Ibyâ' 'Ulûm al-Dîn karya alGhazâlî yang terbilang sebagai karya ulama klasik yang mampu menyajikan fiqh dalam format sebagai wahana dakwah.

68 'Abd al-Raḥmân 'Abd al-Khâliq, Awlawiyyât al-'Amal al-Islâmî (t.t.: t.tp., 1988).

69 Ghâlib 'Abd al-Kâfî al-Qurshî, Awlawiyyât al-Qânûn al-Siyâsîyah (Manșûrah: Dâr alWafâ', 1990). 
al-Islâmîyah karya Muḥammad b. Nafí al-'Ulyânî, ${ }^{70}$ serta yang lainnya adalah buku-buku yang bermuatan pemikiran prioritas dalam kajian hukum praktis.

\section{Urgensi Ijtihâd Maqâș̣idî di Era Kontemporer}

Sebuah konferensi internasional digelar di Convention Hall kampus UIN Sunan Kalijaga, Kamis; 17 Januari 2013 menghadirkan Jasser Auda selaku narasumber yang didampingi M. Amin Abdullah; mantan rektor UIN Sunan Kalijaga dengan tema "Shaping Islamic Tomorrow Today Maqasid Perspective Towards A New Paradigm of Islamic Research" (Merancang Islam Masa Depan melalui Pendekatan Maqâsid menuju Paradigma Baru dalam Studi Keislaman).

Jasser Auda melontarkan sebuah pandangan tentang pentingnya sebuah pemikiran yang berbasis maqậid sharîah, khususnya dalam merespons problematika kontemporer demi mengantarkan umat Islam menuju kejayaan. Jasser menjelaskan bahwa dalam Islam ada delapan dan enam pasangan tepi, yang apabila disatukan akan membawa kejayaan umat dan kebahagiaan dunia dan akhirat. Dahulu saat umat Islam berpegang teguh pada keislaman secara arif dan konsisten, delapan pasangan tepi itu tidak pernah menjauh. Akan tetapi, seiring waktu, terjadi degradasi paham dan terapan Islam, delapan pasangan tepi itu terlihat menjauh dan memunculkan jurang-jurang yang mengenaskan. ${ }^{71}$

Tegas Jasser, delapan pasangan tepi yang semakin berjauhan itu sebenarnya adalah delapan gap antara yang diharapkan dan yang ada, menyangkut pengembangan keilmuan oleh umat manusia dan penerapannya di tengah-tengah kehidupan. Lebih lanjut mengenai delapan pasangan tepi itu dan bagaimana cara menjembatani, adalah: ${ }^{72}$

Pertama, antara worldview islami dan worldview ilmiah. Islam yang dibawa Nabi Muhammad lahir sebagai worldview ilmiah, sistematis, dan konsekuen. Wahyu pertama al-Qur'ân menyeru kepada manusia untuk iqra' (membaca). Menyeru untuk mengumpulkan tanda-tanda wujud dari berbagai arah dan disiplin ilmu. Manusia diarahkan untuk mengumpulkan

\footnotetext{
70 Muḥammad b. Nafí al-'Ulyânî, Ahammîyat al-Jihâd fî Nashr al-Da'wah al-Islâmîyah wa alRadd 'alâ al-Ṭawâif al-Dâllah (t.t.: Dâr al-Ṭayyibah, 1985).

71 Jasser Auda, "Shaping Islamic Tomorrow Today Maqasid Perspective towards a New Paradigm of Islamic Research", Seminar Internasional di UIN Sunan Kalijaga (Kamis, 17 Januari 2013).

72 Ibid.
} 
tanda-tanda kebesaran Allah dari ilmu janin, ilmu pendidikan, ilmu psikologi, ilmu ilmu yang lainnya... dan ilmu agama. Dengan akalnya pula manusia diarahkan untuk mengiatkan berbagai ilmu untuk menemukan hakikat ketauhidan Allah. Jika manusia dapat menemukan hakikat ketauhidan Allah melalui akal dan ilmunya akan bisa membawa kemuliaan akhlak. Seperti yang pernah dicapai kaum Muslimin saat peradaban Islam berjaya dulu.

Kedua, pasangan tepi antardisiplin (ilmu). Menurut Jaser, jurangjurang antardisiplin ilmu bila tidak diperjuangkan untuk diinterkoneksikan kembali akan menghalangi tugas-tugas luhur manusia sebagai khalifah.

Ketiga, pasangan tepi antara drives dan discipline. Islam selalu mengajak untuk aktif mendialogkan antara fiqh dengan lingkungan, agar memberi manfaat melalui upaya memerakarsai kebaikan (al-amr bi al-ma'rûf) dan mencegah keburukan (al-naby 'an al-munkar).

Keempat, pasangan tepi antara "Penulis" dan "Pembaca". Sepanjang sejarah peradaban emas Islam, warga yang berakal, berilmu, dan memiliki integritas diandalkan untuk melestarikan kehidupan beragama dan bermasyarakat yang madani, tidak hanya bergantung pada aturan hukum saja, apalagi hukum pidana.

Kelima, pasangan tepi antar-mazhab Islam. Penerapan sharî‘ah Islam pada tingkatan yang lebih tinggi, yakni filsafat dan akhlak, akan terbukti melarutkan kekakuan antarmazhab. Karena dari hasil penelitian, kata Jasser, terbukti bahwa kekakuan itu adalah hasil dari perselisihan politik sepanjang sejarah Islam.

Keenam, pasangan tepi antara komunitas Muslim dan masa lalunya. Menurut Jaser, umat Islam hendaknya memiliki komitmen untuk membangun atas warisan keilmuan Islam, namun tetap kritis terhadap warisan yang bertentangan dengan komitmen dasar yang berwawasan ilmiah, sistematis, dan konsekuen.

Ketujuh, pasangan tepi antara umat Muslim dan manusia dunia. Jaser berupaya menyatukan umat Muslim dan manusia dunia berdasar komitmen bahwa semua manusia memimpikan kesejahteraan, kedamaian, dan kelestarian lingkungan.

Kedelapan, pasangan tepi antara citra dan cerita intelektual Muslim. Melalui keaktifannya dalam berbagai organisasi dunia, melakukan berbagai penelitian, menulis berbagai karya buku, dan melakukan 
berbagai pengamalan hasil ijtihad intelektualnya. Jaser mengajak semua umat Muslim untuk giat melakukan sesuatu dan berkarya dengan segala kesederhanaan, keterbukaan untuk dikritik, kemurahan, kerendahan hati serta hormat pada ulama, agar citra dan cerita intelektual Muslim bersambut.

Sementara enam pasangan tepi yang menunggu setiap Muslim untuk mendekatkannya atau menyatukannya adalah: 1) Pasangan tepi antara Sang Khalik dengan Hambanya. 2) Pasangan tepi antara manusia dengan lingkungan alamnya, 3) Pasangan tepi antara warga negara dan pemerintahnya, 4) Pasangan tepi antara dua belahan kemanusiaan lakilaki dan Perempuan, 5) Pasangan tepi antara aktivisme islami dan aktivisme gerakan Islam humanis, dan 6) Pasangan tepi antara haves dan have-nots dalam bingkai maqâsid sharî'ah. ${ }^{73}$

Bersama uraian di atas, dengan delapan dan enam pasangan tepi yang diupayakan untuk dipertemukan, adalah nilai-nilai universal yang terkandung dalam ajaran Islam yang, menurut Jasser, kini kurang teraplikasi dalam pola kehidupan umat Islam. Dalam bukunya Maqâsid alSharíah: as Philosophy of Islamic Law A Systems Approach, Jasser menyebutkan bahwa maqâsid sharî'ah memiliki sifat fundamental dan universal, sehingga merupakan landasan dasar agama, hukum, dan keimanan (ușul al-dîn wa qawâ'id al-sharî'ah wa kulliyat al-millah). ${ }^{74}$

Suatu hal yang maklum diketahui bahwa problematika yang dihadapi umat Islam dewasa ini jelas berbeda dengan ragam problem yang terjadi di masa yang lalu. Perbedaan dimaksud bisa berupa perbedaan materi hukum atau konteks hukumnya. Materi hukum senantiasa mengikuti realitas yang terjadi di masyarakat, sebab hukum akan bertindak sebagai pranata sosial guna menciptakan iklim keharmonisan, kerukunan, dan kesejahterahan dalam kehidupan umat beragama. Untuk itu, setiap fatwa hukum akan selalu mengikuti dinamika sosial yang terjadi di masyarakat. Ibn al-Qayyim (w. 751 H.) dalam I'lâm al-Muwaqqi în mengeluarkan sebuah statemen yang cukup mewakili atas responsibilitas hukum Islam terhadap dinamika sosial. Ia menuliskan satu bab khusus yang bertajuk Taghayyur al-Ạ̣kâm bi Taghayyur al-Ažminah wa al-Amkinah wa al-A'râf wa

\footnotetext{
73 Ibid.

74 Jasser Auda, Maqâsid al-Sharîah as Philosophy of Islamic Law: a Systems Approach (London: Washington IIIT, 2008), 20-21.
} 
al-'Adât (perubahan fatwa sebab perbedaan ruang, waktu, adat dan tradisi). ${ }^{75}$

Penyikapan atas problematika yang terus berkembang dengan merujuk hanya kepada sumber-sumber tekstual-parsial adalah sesuatu yang tidak mungkin bisa menyelesaikan persoalan, bahkan menambah persoalan itu sendiri. Sebagai solusi adalah dengan upaya penyambungantangan antara pesan-pesan literal kewahyuan dengan fakta-fakta empiris yang terbaca dalam kehidupan. Hal itu bisa dilakukan dnegan menjadikan nilai-nilai universal Islam (maqâsid sharî‘ah) sebagai landasan ijtihâd, yang terkonsep dalam metodologi ijtihâd maqâsidî́.

Untuk menghadirkan metodologi ijtihâd maqậsidî dalam menyelesaikan problematika kontemporer bisa dilakukan dengan dua cara: pertama, dengan menempatkan nilai-nilai maqâsid yang telah diakui oleh para ulama sebagai landasan fundamental agama yang bersifat baku dan tidak bisa diubah-ubah; kedua, dengan menempatkan nilai-nilai maqâșid pada timbangan tarjîţ apabila terjadi pertentangan yang tidak mungkin dikompromikan. ${ }^{76}$ Penekanan pertama dan paling utama dari cara menghadirkan metodologi ijtihâd maqậidî adalah memegangi hal-hal prinsipil maqâsid sebagai prinsip-prinsip ajaran Islam agar tidak larut dalam arus pemikiran bebas hingga mencerabut asas-asas agama. Ini merupakan sikap untuk mempertahankan identitas nilai-nilai universal yang mengatasnamakan agama (Islam) sebagai filsafat hukumnya dengan nilai-nilai universalitas hukum yang lahir dari aliran-aliran filsafat nonagama, sebagaimana marak diusung oleh para pemikir dari dunia Barat. Perhatian besar terhadap nilai-nilai maqâșid yang bersifat baku dan tidak berubah-ubah ini pada kerangka kerjanya lebih menunjuk pada metode untuk selalu mengelaborasi antara nilai-nilai universal hukum dengan dalil-dalil partikular (al-jam' bayn al-kulliyyât wa al-juz'iyyât) dalam proses penetapan hukum. ${ }^{77}$ Sedangkan dari cara kedua; dengan menempatkan nilai-nilai maqâsid pada timbangan tarjîh, pada kerangka kerjanya lebih menekankan pada penetapan hukum melalui pendekatan sosio-historis dan graduasi masa keberlakuan hukum di masa-masa pembentukannya.

75 Ibn al-Qayyim al-Jawzîyah, I'lâm al-Muwaqqiîn, ed.: Abû Ghumarâ' Aḥmad 'Abd Allah (Jeddah: Dâr Ibn al-Jawzî, 1423 H.), 337-499.

${ }^{76}$ Nûr al-Dîn Mukhtâr al-Khâdimî, al-Ijtihâd al-Maqậsidì: Huijizyatuh, Dawâbituh, Majâlâtuh, Vol. 2 (Qatar: Riâsat al-Mahâakim al-Sharîyah wa al-Shu'ûn al-Dînîyah, 1998), 145-146.

77 Ibid., 148. 
Yakni dengan meninjau kembali konsep munâsabât al-nu₹ûl (sosio-historis turunnya ayat-ayat dan hadîth-ḥadîth aḅkâm) dan nâsikh-mansûkk, termasuk juga pada konsep tarì̄h konvensional yang perlu direkonseptualisasi menurut skala prioritas yang ada pada setiap zaman. ${ }^{78}$

Mereka yang berkecenderungan kepada maqâsid sharî́ah sebagai basis pemikiran sama-sama berupaya untuk mengembangkan ijtihâd maqâsị̂̀̂ ke sejumlah pecahan konsep menurut efektivitas dan tujuan penyelesaian problem hukum. Seperti yang dilakukan oleh Nûr al-Dîn al-Khâdimîsebagaimana hasil pembacaan Jamâl al-Dîn 'Ațîyah-adalah dengan mengeluarkan empat kaidah pecahan: 1) selalu mengaitkan antara dalildalil tekstual dan hukum dengan tujuan-tujuannya (al-nușisw wa al-ạ̣kâm bi maqâsịihbâ); 2) mengorelasikan antara nilai-nilai universal dengan dalildalil parsial (al-jam' bayn al-kulliyyât al-'âmmah wa al-adillah al-khâșsah); 3) prinsip pencapaian kemaslahatan dan menghindari mafsadat mutlak (jalb al-mașâliḥ wa dar' al-mafâsid mutlaqâ); dan 4) mempertimbangkan akibatakibat hukum (itibâr al-mâlât.$^{79}$

Sementara itu, Tâha Jâbir al-'Alwânî dalam pengembangan maqậsid sharí $a h$ dari sebuah konsep ke pendekatan adalah dengan melahirkan tiga pecahan konsep: 1) fiqh al-Aqalliyyât (fiqh minoritas), 2) fiqh al-Awlawiyyât (fiqh prioritas), dan 3) fiqh al-Maqâsiditu sendiri. ${ }^{80}$

Al-Qaraḍ̂âi sendiri menghadirkan sejumlah pecahan konsep ijtihâd maqâșidî, yang menurutnya, digunakan sebagai alternatif dalam merespons problematika kontemporer, yakni yang ia sebut sebagai "wacana fiqh baru" (Naḥw Fiqh Jadîd). Adapun wacana fiqh baru yang dikehendaki adalah sebagai berikut: ${ }^{81}$

1. Fqh al-Maqâsid (Fiqh Universalistik), yaitu pola berfiqh yang tidak terkonstruk pada dalil-dalil literal partikular tetapi juga berpegang kepada prinsip-prinsip universal yang menjadi tujuan hukum Islam; dengan mengembangkan konsep dasar yang telah dirumuskan oleh al-Shâtịî.

\footnotetext{
78 Ibid., Vol. 2, 152-153.

79 'Ațiyah, Naḥw Taf'îl, 186. Sementara dari Nûr al-Dîn al-Khâdimî sendiri dalam bukunya al-Ijtihâd al-Maqâsidî menyebutkannya secara acak dan dalam bentuk deskripsi yang cukup panjang. Lihat al-Khâdimî, al-Ijtihâd al-Maqậidî, Vol. 2, 141-154.

80 al-'Âlwânî, Maqâsid al-Sharî'ah, 63, 95, dan 124.

81 al-Qaraḍ̂wî̀, al-Ṣaḥwah al-Islâmîyah, 6-7. Yûsuf al-Qaraḍ̂âî, al-Ṣậwah al-Islâmîyah min al-Murâhaqah ilâ al-Rushd (Kairo: Dâr al-Shurûq, 2006), 362-363.
} 
2. Figh al-Sunan (Fiqh Alam Semesta), yakni hukum-hukum Allah yang berlaku bagi alam semesta dan dalam kehidupan yang tidak bisa dirubah dan dipungkiri oleh manusia.

3. Fiqh al-Muwâzanât (Fiqh Pertimbangan), yakni mempertimbangkan antara suatu bentuk maslahat dengan bentuk maslahat yang lain, antara suatu bentuk mafsadat dengan bentuk mafsadat yang lain, dan antara maslahat dengan mafsadat apabila keduanya terjadi pertentangan.

4. Fiqh al-Awlawiyyât (Fiqh Prioritas), yakni menempatka segala bentuk perbuatan pada posisi semestinya, dengan tidak membesar-besarkan hal yang kecil dan tidak meremehkan hal yang besar, sehingga segala perbuatan bisa dilakukan secara seimbang.

5. Fiqh al-Ikhtilâf (Fiqh Perbedaan/Komperatif), dimaksudkan sebagai wacana pengetahuan tentang bagaimana menyikapi suatu perbedaan yang terjadi di tengah kehidupan umat manusia, terutama perbedaan pada segi pemikiran yang butuh ditanggapi secara lebih bijaksana dan beretika, karena perbedaan merupakan tabiat dasar bagi umat manusia (QS. Hûd: 118-119).

6. Fiqh al-Mâlât (Fiqh Pertimbangan Akibat-akibat Hukum), yakni dengan memperhatikan dan mempertimbangkan secara lebih matang atas akibat dan konsekuensi tertentu yang bisa ditimbulkan dari setiap ketetapan suatu hukum. Pengamatan atas akibat-akibat hukum ini sangatlah urgen agar suatu ketetapan hukum dapat mencapai tujuan berupa kesejahteraan.

Muhammad 'Imârah dalam pembacaannya atas pemikiran fiqh ala alQaraḍ̂âi menambahkan empat model pemikiran fiqh yang lain dari enam model di atas, yaitu: figh al-Wâqi' (Fiqh Realitas), Fiqh al-Hadârî (Fiqh Peradaban), Fiqh al-Makârim al-Shar'îyah (Fiqh Kemuliaan EtikaMoral), dan Fiqh al-Mustaqbal (Fiqh Masa Depan). ${ }^{82}$ Pada prinsipnya alQaraḍ̂wî memperluas terminologi fiqh dari makna konvensional; yaitu sebagai ilmu pengetahuan tentang hukum-hukum Islam partikular, menjadi fiqh dalam terminologi al-Qur'ân yang bermakna sebagai "pemahaman" ajaran Islam itu sendiri. Apabila fiqh al-Qur'ân ini selalu direvitalisir menurut konteks ruang dan waktu akan selalu mampu

82 Yûsuf al-Qaraḍ̂âî, al-Sunnah Mașdaran li al-Ma'rifah wa al-Hadârah (Kairo: Dâr alShurûq, Cet. Ke-4, 2005), 205, 221, dan 228. 
mengantarkan umat Islam kepada kesejahteraan, keseimbangan, dan kemajuan dalam kehidupan di era kontemporer seperti sekarang ini.

Dari sini dapat dikatakan bahwa ijtihâd maqâsidî̀ adalah sebuah kebutuhan dan keharusan demi mewujudkan fiqh yang responsif atas problematika kontemporer dan simplifikatif dalam penerapannya. Bentuk responsibiltas fiqh semacam inilah yang merupakan bagian dari beberapa karakteristik utama hukum Islam yang universal, dinamis, toleran, dan memudahkan dengan tidak mempersulit manusia dalam mengamalkan ajaran-ajaran keislaman. ${ }^{83}$

Dari penjelasan di atas, terbaca jelas bahwa aplikasi ijtihâd maqậidî dalam menyikapi problematika kontemporer memiliki prinsip, teori, dan metodologi tertentu yang harus dipenuhi. Ia bukanlah suatu cara berpikir yang bebas tanpa kendali metodologi, yang memaksakan kehendak mengeluarkan argumentasi hukum sesuka hati. Para pakar maqâsid sharíah telah banyak merumuskan kerangka metodologi ijtihâd maqâsidî, walaupun tidak ada keseragaman tetapi mereka senantiasa menitik-beratkan pada urgensi keterkaitan 'illah, dalil dan kemaslahatan sebagai tujuan hukum.

\section{Catatan Akhir}

Fiqh Prioritas (fiqh al-Awlawiyyât) sebagai sebuah kajian baru dalam diskursus hukum Islam menempati posisi sebagai salah satu cabang dari konsep ijtihad hukum yang berbasis maqâsid sharî‘ah. Fiqh Prioritas dianggap sebagai proses pengembangan konsep tarjîh maqâșidî yang dikompromikan dengan Fiqh Realitas (Fiqh al-Wâqi ). Ia sengaja dirumuskan oleh para pakar maqâsid untuk mengimplementasikan pengetahuan atas nilai-nilai maqâsid sharíah ke dalam tataran hukum praktis dan mewujudkan relevansinya pada dimensi ruang dan waktu.

Fiqh Prioritas dengan seperangkat kaidah-kaidahnya layak difungsikan sebagai acuan dalam penetapan hukum Islam (ijtihâd ala ḩkâm). Sebab kehadiran konsep ini berpijak pada nilai-nilai yang terkandung dalam al-Qur'ân dan Sunnah tentang adanya pencapaian skala prioritas tertentu dalam pengamalan sharî'ah Islam. Fiqh Prioritas juga berpijak pada adanya konsep tadarruj al-aḅkâm (graduasi penetapan hukum Islam) di zaman kenabian, yang menetapkan pilihan hukum tertentu menurut relevansi ruang dan waktu demi tercapaianya tujuan

83 Yûsuf al-Qaraḍâwi, Madkhal li Dirâsat al-Sharîah al-Islâmîyah (Kairo: Maktabah Wahbah, Cet. Ke-6, 2009), 90. 
sharî‘ah Islam itu sendiri. Secara epistemologis, Fiqh Prioritas akan mempertimbangkan dan mengukur tingkat kemaslahatan dan kemafsadatan tertentu yang ditimbulkan oleh suatu hukum baik yang bersandar kepada dalil tekstual maupun realitas sosial menurut tingkatantingkatannya.

\section{Daftar Rujukan}

'Alwânî (al), Tâha Jâbir. Maqâsid al-Sharî‘ah. Beirut: Dâr al-Hâdî, 2001. "Asâl (al), Aḥmad. "al-Dâ'îyah al-Faqîh al-Shaykh Yûsuf al-Qaradâwî wa Masîrah Khamsîna 'Âman fî al-Da'wah ilâ Allah", dalam dalam 'Abd al-Qâdir Mahmûd al-Bakâr (ed.), Yûsuf al-Qaradânî:Kalimât fî Takrîmih wa Buhûth fî Fikrih wa Fiqhih, Vol. 1. Kairo: Dâr al-Salâm, 2004.

'Âshûr, Muhammad Tâhir b. Maqâsid al-Sharîah al-Islâmîyah. Kairo: Dâr al-Salâm, Cet. Ke-2, 2007.

Asnawî (al), Jamâl al-Dîn "Abd al-Rahîm. "Nihạyat al-Sûl" dalam Muḥammad b. al-Ḥasan al-Badakhshî, Manâhij al-'Uqûl, Vol. 1. Beirut: Dâr al-Fikr, 2001.

'Asqalânî (al), Ibn Hajar. Fatḥ al-Bârî: Sharḥ Șahîh al-Bukhârî, 'Abd alQâdir Shaybah al-Hamd (ed.), Vol. 1. Riyad: Maktabah al-Mulk alFahad al-Watanîyah, 1421.

'Ațiyah, Jamâl al-Dîn dan Zuhaylî (al), Wahbah. al-Tajdîd al-Figh al-Islâmî. Damaskus: Dâr al-Fikr, 2000.

'Ațîyah, Jamâl al-Dîn. Naḥw Taf'îl Maqâșid al-Sharîah. Damaskus: Dâr alFikr, 2001.

Auda, Jasser. "Shaping Islamic Tomorrow Today Maqasid Perspective towards a New Paradigm of Islamic Research", Seminar Internasional di UIN Sunan Kalijaga, Kamis, 17 Januari 2013.

Auda, Jasser. Maqâsid al-Sharîah as Philosophy of Islamic Law: a Systems Approach. London: Washington IIIT, 2008.

'Azzat, Hibbah Ra'ûf. "al-Mar'ah wa Tayyâr al-Wasaṭiyah al-Islâmîyah", dalam 'Abd al-Qâdir Maḥmûd al-Bakâr (ed.), Yûsuf al-Qaradâwî: Kalimât fî Takrimih wa Buhûth fî Fikerih wa Fiqhih, Vol. 2. Kairo: Dâr alSalâm, 2004.

Bayḍ̂âî (al), Naṣir al-Dîn. "Minhâj al-Wuṣûl fî 'Ilm al-Uṣûl", dalam Muhammad b. Hasan al-Badakhshî, Manâhij al- 'Uqûl fî̀ 'Tlm al-Ușûl, Vol. 3. Beirut: Dâr al-Fikr, 2001. 
Bik, Muhammad al-Khuḍarî. Târîkh al-Tashrî al-Islâmî, ed.: Mahmûd 'Abbâs. Kairo: Mu'assasat al-Mukhtâr, 2007.

Dasûqî (al), Muḥammad. "Manâhij Tadrîs fî Fiqh al-Islâmî" dalam

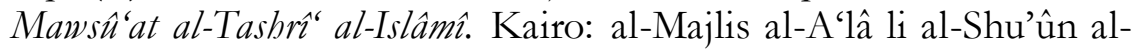
Islâmîyah, Cet. Ke-2, 2009.

Dayb (al), 'Abd al-'Azîim. "Kata Pengantar: "Tarjamah Mûjizah 'an alShaykh Yûsuf al-Qaraḍ̂âî, dalam 'Abd al-Qâdir Mạ̣mûd al-Bakâr (ed.), Yûsuf al-Qaradâwî: Kalimât fî Takrimih wa Buḥ̂th fî Fikrih wa Fiqhih, Vol. 1 dan 2. Kairo: Dâr al-Salâm, 2004.

Ghazâlî (al), Abû Hâmid. al-Mustaşẩ min 'Ilm al-Ușûl, ed. Muhammad 'Abd al-Salâm 'Abd al-Shâfî. Beirut: Dâr al-Kutub al-'Ilmîyah, 2000. Hilâlî (al), Majdî. Min Fiqh al-Awlawiyyâat fî al-Islâm. Kairo: Dâr al-Tawzî' wa al-Nashr al-Islâmîyah, 1994.

'Imârah, Muhammad. al-Ṣaḥwah al-Islâmîyah fî̀ 'Uyûn Gharbîyah. Kairo: Nahḍat Miṣr, 1997.

-----. al-Sạ̣wah al-Islâmîyah wa al-Tạ̣addî al-Ḥadârî. Kairo: Dâr al-Shurûq, 1997.

Jawzîyah (al), Ibn al-Qayyim. I'lâm al-Muwaqqi'în, ed.: Abû Ghumarâ' Aḥmad 'Abd Allah. Jeddah: Dâr Ibn al-Jawzî, 1423 H.

Jundî (al), Anwâr. Itâr Islâmî li al-Ṣaḥwah al-Islâmîyah. t.t.: Dâr al-Fadịlah, 2000.

Khâdimî (al), Nûr al-Dîn Mukhtâr. al-Ijtihâd al-Maqâșidî: Huijiyatuh, Dawâbituh, Majâlâtuh, Vol. 2. Qatar: Riâsat al-Mahâkim al-Sharîyah wa al-Shu'ûn al-Dînîyah, 1998.

Khalâf, 'Abd al-Wahhâb. Khulạsah Târîkh al-Tashrì al-Islâmî. Kuwait: Dâr al-Qalam, 1996.

Khâliq (al), 'Abd al-Raḥmân 'Abd. Awlawiyyât al-'Amal al-Islâmî. t.t.: t.tp., 1988).

Manzûir (al), Jamâl al-Dîn Muhammad b. Mukarram b. 'Alî b. Lisân al'Arab, 'Abd Allah 'Alî al-Kabîr (ed.). Kairo: Dâr al-Ma'ârif, t.th.

Mawardi, Ahmad Imam. Fiqh Minoritas: Figh al-Aqalliyat dan Evolusi Maqasid al-Syari'ah dari Konsep ke Pendekartan. Yogyakarta: LKiS, 2010. Muhammad, 'Alî Jum'ah. al-Madkhal ilâ Dirâsat al-Madhâhib al-Fiqhîyah. Kairo: Dâr al-Salâm, 2004.

Mûsâ, Muhạmmad Yûsuf. al-Islâm wa Ḥâjah al-Insânŷyah ilayh. Kairo: alMajlis al-A'lâ li Shu'ûn al-Islâmîyah, 2003. 
Qaraḍ̂wî̀ (al), Yûsuf. al-Siyâsah al-Shar'îyah fî Daw' al-Nusûș al-Shar'îyah wa Maqâsiduhâ. Kairo: Maktabah Wahbah, 1998.

-----. al-Sunnah Mașdaran li al-Ma'rifah wa al-Ḥadârah. Kairo: Dâr alShurûq, Cet. Ke-4, 2005.

-----. al-Fiqh al-Islâmî bayn al-Aṣalah wa al-Tajdîd. Kairo: Maktabah Wahbah, 1999.

-----. al-Halâl wa al-Ḥarâm fî al-Islâm. Kairo: Maktabah Wahbah, Cet. Ke29, 2007.

-----. al-Sạ̣wah al-Islâmîyah bayn al-Ikhtilâf al-Mashrû́ wa al-Tafarruq alMadhmûm. Kairo: Dâr al-Shurûq, 2006.

----. al-Ṣaḥwah al-Islâmîyah bayn al-Juḥ̂ud wa al-Tațarruf. Kairo: Dâr alShurûq, 2001.

----. al-Ṣahwah al-Islâmîyah min al-Murâhaqah ilâ al-Rushd. Kairo: Dâr alShurûq, 2006.

-----. al-Ṣahwah al-Islâmîyah wa Humûm al-Watan al-'Arabî wa al-Islâmî. Kairo: Maktabah Wahbah, 1997.

----. Awlawiyyât al-Harakah al-Islâmîyah fi al-Marḅalah al-Qâdimah. t.t.: t.p., t.th

----- Dirâsah fî Fiqh Maqâsid al-Sharî‘ah. Kairo: Dâr al-Shurûq, 2006.

----. Fî̀ Fiqh al-Awlawiyyât:Dirâsah Jadîdah fî Daw' al-Qur'ân wa al-Sunnah. Kairo: Maktabah Wahbah, Cet. Ke-7, 2005.

----. Liqâ'ât wa Muhâawarât ḥawl Qadâyâ al-Islâm wa al-'Aṣr. Kairo: Maktabah Wahbah, 2001.

-----. Madkhal li Dirâsat al-Sharîah al-Islâmîyah. Kairo: Maktabah Wahbah, Cet. Ke-6, 2009.

----. Taysîr al-Figh li al-Muslim al-Ma 'âsir fî Daw' al-Qur'ân wa al-Sunnah. Kairo: Maktabah Wahbah, 2004.

Qarâfî (al), Shihâb al-Dîn. Sharḥ Tanqị̂̉ al-Fuṣul, ed.: Șidqî Jamîl al-'Ațâr. Beirut: Dâr al-Fikr, 2004.

Qaț̣ân (al), Mannâ‘. Târîkh al-Tashrî‘ al-Islâmî:al-Tashrî wa al-Fiqh. Riyad: Maktabat al-Ma'ârif, Cet. Ke-2, 1996.

Qurhudâni (al), 'Alî Muhy al-Dîn. "Fiqh al-Qaraḍ̂âî fî al-Zakâh”, dalam 'Abd al-Qâdir Maḥmûd al-Bakâr (ed.), Yûsuf al-Qaradâwî: Kalimât fî Takrîmih wa Buḥ̂th fî Fikrih wa Fiqhih, Vol. 2. Kairo: Dâr al-Salâm, 2004. 
Qurshî (al), Ghâlib 'Abd al-Kâfî. Awlawiyyât al-Qânûn al-Siyâsîyah. Manșûrah: Dâr al-Wafâ', 1990.

Raysûnî (al), Aḥmad dan Bârût, Jamâl. al-Ijtihâd bayn al-Naṣs wa al-Wâqi wa al-Maslaḥah. Damaskus: Dâr al-Fikr, 2000.

Raysûnî (al), Aḥmad. Nažarîyat al-Maqâsịid ind al-Shâtibî. HemdonVirginia: The International Institute of Islamic Thought, Cet. Ke-4, 1995.

Râzî (al), Fakhr al-Dîn. al-Maḥṣulfî̀ 'Ilm Ușûl al-Fiqh, Vol. 2. Riyad:Jâmi'at al-Imâm Muhammad b. Su'ûd, t.th.

Shâțibî (al), Abû Ishâq. al-Muwâfaqât fî̀Ușul al-Sharî'ah, Vol. 1, ed.: 'Abd Allah Darrâz. Kairo: Maktabah Tawfiqîyah, t.th.

Tâbî‘, Hânî Muhammad. "al-Shaykh al-Qaraḍ̂wî wa Manhajuh alWasatîyah al-Islâmîyah", dalam "Abd al-Qâdir Mạ̣mûd al-Bakâr (ed.), Yûsuf al-Qaradâwî: Kalimât fî Takrîmih wa Buḥ̂th fî Fikrih wa Fiqhih, Vol. 2. Kairo: Dâr al-Salâm, 2004.

Taymîyah, Taqiy al-Dîn Aḥmad b. Majmû'at al-Fatâwâ, ed.: 'Abd alRahmâ al-Najadîr, Vol. 1. Riyad: al-Malik Fahad b. 'Abd al-'Azîz Ali Su'ûd, t.th.

'Ulyânî (al), Muḥammad b. Nafí'. Ahammîyat al-Jihâd fî Nashr al-Da'wah alIslâmîah wa al-Radd 'alâ al-Ṭawâ'if al-Dâllah. t.t.: Dâr al-Ṭayibah, 1985.

Wakîlî (al), Muhammad. Fiqh al-Awlawiyyât Dirâsah fî al-Dawâbit. HendonVirginia: The International Institute of Islamic Thought, 1997.

Zarkashî (al), Badr al-Dîn. al-Baḥr al-Muhît, Vol. 4. Kuwait: Wizârat alAwqâf wa al-Shu'ûn al-Islâmîyah, 1988. 